\title{
Body satisfaction and use anabolic steroids perceptions of adolescents
}

\author{
Ubirajara de Oliveira', Danilo Sales Bocalini', José Martins Filho²
}

\begin{abstract}
Background: It is known that adolescence is a phase of transformation subject to innumerable influences. Objective: The objective of this study was to identify the level of body satisfaction among male adolescents practicing bodybuilding and perception and value attributed to the use of anabolic steroids (AS). Methods: The sample consisted of 3150 male adolescents aged 15 to 21 years. The adolescents were submitted to a questionnaire with 41 questions containing several elements detected such as: the level of body satisfaction, the bodybuilding practice proposing body changes and the possible use of AS. Results: The main results were attributed to the high level of satisfaction for body image variables from the members of their social group in $1883\left(60 \%, X^{2}=26.361 ; p<0.005\right)$, body mass 1552 $\left(50 \% ; X^{2}=55.374 ; p<0.005\right)$ and muscle mass $1199\left(39 \%, X^{2}=10.405 ; p<0.005\right)$. Additionally, $1243\left(39 \% ; X^{2}=31.926 ; p<0.005\right)$ adolescents confirm the possibility of use; the preference for faster means to achieve changes in their bodies, even knowing about health risks was $1347\left(43 \% ; X^{2}=31.926 ; p<0.005\right)$. On the knowledge of the effects to the point of refusing their involvement related to the use of AS with aesthetic objectives $1152\left(36 \% ; X^{2}=45.758 ; p<0.005\right)$ students affirm that they did not know, however, they would still use it, with statistically significant observed differences. Conclusion: Although it is possible to consider a high level of satisfaction for the variables associated with body image, adolescents consider the use of AS to achieve changes in their bodies by faster means, despite knowing about health risks even without knowledge of the effects related to the use of AS for aesthetic purposes.
\end{abstract}

Keywords: Adolescents; Anabolic Steroids; Body Image; Resistance Training.

\section{INTRODUCTION}

Adolescence is understood as a period of intense biological transformations and sociocultural changes. At this stage the body takes on a significant dimension in the life of the adolescent and due to the corporal transformations providing anxiety increase, creation of fantasies, causing situations or moments of estrangement or social isolation ${ }^{(1)}$. Furthermore the body image is strongly influenced by self-esteem and self-assessment, rather than the external evaluation determined by other subjects ${ }^{(2)}$. Slater et al..$^{(3)}$ have identified that media exposure, especially in adolescent males who tend to gain body mass, to be strongly linked to the possible use of chemical substances for bodily alteration associated with the culture of appearance, providing a market to be explored in these contemporary societies in which there is an ideal man pattern ${ }^{(4)}$. This valorization of the muscular body envisions the emergence of new body patterns that are not related to humanistic social values and much more linked to irresponsible corporal consumerism ${ }^{(5)}$. In this context, regardless of age or sex, the biosocial is affected between the search for sensation and the use of anything for bodily alteration, and despite recognizing the risks of using anabolic steroids (AS), adolescents on behalf of the ideal model are subject to consumption ${ }^{(6)}$.

The popularity of the practice of bodybuilding among adolescents has dramatically increased over the last decade $\mathrm{e}^{(7)}$, and is considered an important modality in providing significant morphological changes, which is associated with the perspective of the perfect body ${ }^{(8)}$ with or without the use of ergogenic factors with emphasis on $A S^{(7)}$. The indiscriminate use of AS induces adverse effects on the musculoskeletal, cardiovascular, endocrine, and hepatic systems, as well as having psychological effects ${ }^{(9)}$. However, even with this information already available in the literature studies ${ }^{(10,11)}$ indicate that adolescents tend to use in the search of satisfaction with the body. However, scientific studies on the prevalence or incidence of AS use in adolescents are still scarce. Evidence suggests that the use of AS increases among young people of different social classes and may represent a major public health problem. Thus, the objective of this study was to identify the level of body satisfaction among male adolescents practicing bodybuilding and perception and value attributed to the use of AS. 


\section{METHODS}

\section{Sample}

After approval by the Research Ethics Committee of the Faculty of Medical Sciences of the State University of Campinas (906/2008) and the Secretary of Education of the State of São Paulo, a consent document was signed by 3150 students regularly enrolled males aged 15 to 21 years of 30 schools in the city of São Paulo (eastern region) voluntarily participated in the study. The following exclusion criteria were adopted: students who did not practice strength training and were outside the age range established for the study.

\section{Procedures}

Considering the study design and using the equation $\mathrm{n}=\mathrm{N}$.no / $\mathrm{N}+\mathrm{no}$, the estimated simple random sample to be used was 2560. The adolescents (strength training practitioners) were submitted to a questionnaire with 41 questions after a pilot test with 54 questions that regularized the instrument based on the Likert Scale of 5 (five) categories containing several elements detected, such as: the level of body satisfaction, the practice of bodybuilding by proposing body changes and the possible use of $\mathrm{AS}^{(12)}$.

\section{Statistical analysis}

For statistical analysis, the IBM SPSS Statistics Software 16 program was used. The Qui-square test was used to identify differences between groups. A significance level of $p<0.05$ was according to previously publication ${ }^{(13)}$.

\section{RESULTS}

As there was dispersion in some points of the scale, agglutination was done at both extremes of the scale, thus, a high level of satisfaction was observed for body image variables from members of their social group in 1883 (60\%; $X^{2}=26.361$;

Table 1. Body image satisfaction of adolescent and the use of androgenic anabolic steroids

\begin{tabular}{|c|c|c|c|c|c|c|}
\hline \multirow{3}{*}{ Body image satisfaction } & \multicolumn{6}{|c|}{ Would use androgenic anabolic steroids } \\
\hline & \multicolumn{2}{|c|}{ Yes } & \multicolumn{2}{|c|}{ No } & \multicolumn{2}{|c|}{ Total } \\
\hline & $\mathbf{n}$ & (\%) & $\mathbf{n}$ & (\%) & $\mathbf{n}$ & $(\%)$ \\
\hline \multicolumn{7}{|l|}{ School friends evaluation } \\
\hline Satisfied & 1883 & 60 & 730 & 23 & 2613 & 83 \\
\hline No opinion & 252 & 8 & 56 & 2 & 308 & 10 \\
\hline Dissatisfied & 174 & 5 & 55 & 2 & 229 & 7 \\
\hline \multicolumn{7}{|l|}{ Body mass } \\
\hline Satisfied & 1552 & 50 & 456 & 15 & 2008 & 65 \\
\hline No opinion & 144 & 5 & 68 & 2 & 212 & 7 \\
\hline Dissatisfied & 613 & 18 & 317 & 10 & 930 & 28 \\
\hline \multicolumn{7}{|l|}{ Muscle mass } \\
\hline Satisfied & 1199 & 39 & 490 & 15 & 1689 & 54 \\
\hline No opinion & 471 & 15 & 154 & 5 & 625 & 20 \\
\hline Dissatisfied & 639 & 20 & 197 & 6 & 836 & 26 \\
\hline
\end{tabular}

$\mathrm{gl}=4 ; \mathrm{p}<0.005)$, body mass $1552\left(50 \% ; \mathrm{X}^{2}=55.374 ; \mathrm{gl}=4 ; \mathrm{p}<0.005\right)$ and muscle mass 1199 (39\%; $\left.X^{2}=10.405 ; g=4 ; p<0.005 \%\right)$.

The results focused on the evaluation of their corporeity maintained their positive evaluation can be observed on table 1. However, the possibility of using the androgenic AS was observed, since the lowest index was exactly the specific question of the musculature with a total of $639(20 \%)$ adolescents manifesting themselves with a tendency to be involved with AS, coinciding with the potential for possible change with the use of this illicit drug. The second negative evaluation item was the question of dissatisfaction with body mass $613(19 \%)$. A total of 1333 (42\%) adolescents reported having the objective with their health, when they appropriated this activity $\left(X^{2}=16.895, g l=4 ; p<0.005\right)$. However, as can be

Table 2. Strength training practice and use androgenic anabolic steroids of adolescents

\begin{tabular}{|c|c|c|c|c|c|c|}
\hline \multirow{3}{*}{ Strenght training practice } & \multicolumn{6}{|c|}{$\begin{array}{l}\text { Would use androgenic anabolic } \\
\text { steroids }\end{array}$} \\
\hline & \multicolumn{2}{|c|}{ Yes } & \multicolumn{2}{|c|}{ No } & \multicolumn{2}{|c|}{ Total } \\
\hline & $\mathbf{n}$ & (\%) & $\mathbf{n}$ & (\%) & $\mathbf{n}$ & (\%) \\
\hline \multicolumn{7}{|l|}{ Aim } \\
\hline Health & 1333 & 42 & 476 & 15 & 1809 & 57 \\
\hline Others & 169 & 5 & 91 & 2 & 260 & 7 \\
\hline Aesthetics & 870 & 28 & 274 & 8 & 1144 & 36 \\
\hline \multicolumn{7}{|l|}{ Local practice } \\
\hline Gym & 2222 & 70 & 819 & 26 & 3041 & 96 \\
\hline Others & 16 & 0,5 & 14 & 1 & 30 & 1,5 \\
\hline Club & 71 & 2 & 8 & 0,5 & 79 & 2,5 \\
\hline \multicolumn{7}{|l|}{ Profissional guidelence } \\
\hline Often & 559 & 18 & 207 & 6 & 766 & 24 \\
\hline Eventually & 1549 & 49 & 543 & 17 & 2092 & 66 \\
\hline Never & 201 & 7 & 91 & 3 & 292 & 10 \\
\hline \multicolumn{7}{|l|}{ Desire for bodily alteration } \\
\hline Muscle growth & 1240 & 40 & 624 & 20 & 1864 & 60 \\
\hline Would not do anything & 175 & 6 & 88 & 1 & 263 & 7 \\
\hline Improvement of overall appearance & 894 & 28 & 129 & 4 & 1023 & 32 \\
\hline \multicolumn{7}{|l|}{ Rapid body modification } \\
\hline I agree & 1459 & 46 & 592 & 19 & 2051 & 65 \\
\hline I have no opinion & 379 & 12 & 93 & 3 & 472 & 15 \\
\hline I disagree & 471 & 15 & 156 & 5 & 627 & 20 \\
\hline \multicolumn{7}{|l|}{ Get stronger faster } \\
\hline I agree & 1238 & 39 & 479 & 15 & 1717 & 54 \\
\hline I have no opinion & 218 & 7 & 47 & 2 & 265 & 9 \\
\hline I disagree & 853 & 27 & 315 & 10 & 1168 & 37 \\
\hline \multicolumn{7}{|l|}{$\begin{array}{c}\text { Concern about drug-related } \\
\text { appearance }\end{array}$} \\
\hline I agree & 774 & 24 & 244 & 7 & 1018 & 31 \\
\hline I have no opinion & 578 & 18 & 163 & 5 & 741 & 23 \\
\hline I disagree & 958 & 30 & 530 & 16 & 1488 & 46 \\
\hline
\end{tabular}


seen in table 2, for the items: gymnastics practice 2222 (70\%; $\left.X^{2}=35,970 ; g=4 ; p<0.005\right) ;$ presence of professional guidance $\left(X^{2}=11.648 ; g l=4 ; p<0.005\right)$ and rapid body alteration 1459 $\left(46 \% ; X^{2}=28.305 ; g l=4 ; p<0.005\right)$ related to the possible objective use $\left(20 \% ; X^{2}=21.869, g l=4 ; p<0.005\right)$, to the consumption of these drugs and the concern with appearance 1238 (39\%; $\left.X^{2}=73.913 ; \mathrm{gl}=4 ; \mathrm{p}<0.005\right)$. In addition, 1240 (40\%) of the adolescents evaluated presented signs of predisposition to the consumption of AS to meet the need for bodily alteration increase of mass, with statistically significant differences being observed $\left(X^{2}=3.084 ; \mathrm{gl}=4 ; \mathrm{p}<0.005\right)$.

As can be observed in Table 3, 1243 (39\%; $X^{2}=31.926$; $\mathrm{gl}=4 ; \mathrm{p}<0.005$ ) adolescents confirm the possibility of use; the preference for faster means to achieve changes in their bodies, even knowing about health risks, was 1347 (43\%; $X^{2}=31.926$, $\mathrm{gl}=4 ; \mathrm{p}<0.005)$. On the knowledge of the effects to the point of refusing their involvement related to the use of AS with aesthetic objectives $1152\left(36 \%, X^{2}=45.758\right.$; gl= 4; $\left.p<0.005\right)$ students say they do not know, however, showing statistically significant differences.

\section{DISCUSSION}

In the present study we have identified that the understanding of the body from the outward gaze reinforces the possibility of masking the truth in the name of a personal status and power in the group in which it is inserted. The perfect body cult has become a way of life, the fascinating promise of an additional gain of health, youth and beauty has conquered an unprecedented space in all spheres of our daily

Table 3. Knowledge about androgenic anabolic steroids use of adolescents

\begin{tabular}{|c|c|c|c|c|c|c|}
\hline \multirow{3}{*}{$\begin{array}{c}\text { Androgenic anabolic } \\
\text { steroids }\end{array}$} & \multicolumn{6}{|c|}{ Would use androgenic anabolic steroids } \\
\hline & \multicolumn{2}{|c|}{ Yes } & \multicolumn{2}{|c|}{ No } & \multicolumn{2}{|c|}{ Total } \\
\hline & $\mathbf{n}$ & (\%) & $n$ & (\%) & $\mathbf{n}$ & (\%) \\
\hline \multicolumn{7}{|l|}{$\begin{array}{c}\text { The appearance and } \\
\text { use of drugs to speed up } \\
\text { modifications }\end{array}$} \\
\hline Not & 774 & 25 & 244 & 8 & 988 & 33 \\
\hline I have no opinion & 292 & 9 & 67 & 2 & 359 & 11 \\
\hline Yes & 1243 & 39 & 530 & 17 & 1773 & 56 \\
\hline \multicolumn{7}{|l|}{$\begin{array}{l}\text { Faster means even } \\
\text { knowing the risks to health }\end{array}$} \\
\hline Not & 666 & 21 & 223 & 8 & 889 & 29 \\
\hline I have no opinion & 296 & 9 & 89 & 2 & 385 & 11 \\
\hline Yes & 1347 & 43 & 529 & 17 & 1876 & 60 \\
\hline \multicolumn{7}{|l|}{$\begin{array}{l}\text { They know and would } \\
\text { refuse to use }\end{array}$} \\
\hline Not & 1152 & 36 & 350 & 11 & 1502 & 47 \\
\hline I have no opinion & 374 & 12 & 111 & 4 & 485 & 16 \\
\hline Yes & 783 & 25 & 380 & 12 & 1163 & 37 \\
\hline
\end{tabular}

life ${ }^{(14)}$. It is noted the current appreciation of the human body everywhere and the multiplication of techniques and therapies widely disseminated and progressively accessible so that each one perfects and intensifies good form, beauty, physical and mental vigor ${ }^{(15)}$. The possibility of associating the practice of bodybuilding with the purpose of corporal alteration with the use of AS was the second variable analyzed by the study. Considered was the practice of bodybuilding, reasons for its weekly frequency, place of accomplishment, existence of professional orientation, whether they provoke a rapid change in the appearance of the adolescents and whether they would use the AS with aesthetic objectives. The practice of bodybuilding has shown a significant evolution over recent years and the approach of adolescents to bodybuilding programs is linked to other reasons, much more related to social group relationships than to goals of better quality of life or health ${ }^{(16)}$. Adolescents are more concerned with the values added to it and with the visibility that such programs can achieve.

Our data demonstrated that bodybuilding subjects were influenced to use AS for the purpose of body alteration that has partial confirmation only with the finding of this mismatch between health goal and strategies of aesthetic reconstruction and construction in the search for the rapid alteration of appearance. Considering only this result we can suggest that the search for body alteration would find in the practice of bodybuilding as well as in the environment influences the use of $A S^{(1)}$. In addition, the body wanted in the bodybuilding academies inscribes in its own muscles, different procedures that aim at its extreme potentiation, among other reasons, because the physical commitment refers directly to a vision of the world rooted, among other aspects, in virility and honor, in vigor and in body strength, in image, in determination, and in self-denial ${ }^{(17)}$.

Based on these findings, it is noted that the adolescent approach to the practice of bodybuilding that presents a potential possibility of body modeling would be more related to the predisposition to use AS with an aesthetic objective in any circumstances than with dissatisfaction with body characteristics or with health. In an attempt to understand the real intentions of adolescents, we observed the third variable in which we sought data on adolescents' concerns about the appearance and use of drugs to speed up modifications, faster means for changes in their bodies even when they knew about health risks and even knowing about the AS they would refuse to use it. Our data demonstrate that there is no knowledge to the point of promoting the refusal of its consumption, thus, in the voluptuousness of reaching the desired body, they favor the use / abuse of any of the substances presented. This data is extremely relevant, since it confirms the predisposition to consumption even though it is unaware of the real health effects, remaining only linked to the aspects of social pressure on the adolescent body. What was possible to notice was that 
initially the naive consumption of specific supplements for the bodybuilders diet composes the universe in the strategies of potentiation of the body of the adolescent the use of the AS, unlike the consumption of those substances, is a very veiled practice, although prohibited AS have great circulation within the academies and are achieved through strategies as diverse as invisible ${ }^{(7)}$.

A body whose muscles are the protagonists of the contemporary spectacle always requires new ways to increase power, robustness, endurance with visibilized anatomies to be "consumed." Based on these considerations, we can add that in several situations the consumption of AS can be linked many times to the problems of social and affective living. Thus, the academy environment, to a certain extent, meets some of these needs by showing a rapid and thought-provoking way of dealing with such facts ${ }^{(8,18)}$. We attempted to identify the possible differences between the evaluated population and the target population, using the variables, level of satisfaction about their body image (own opinion) and possible alteration related to the use of AS. The research instrument used detected a possible relationship between the adolescent and his / her body based on the body's own perception, aesthetic questions, body weight and the musculature of the subjects who were enrolled in High School, and the desires of corporal alteration related to the practice of bodybuilding to the possible use of AS for aesthetic purposes. From these considerations, it has been observed that this understanding of the body from the outside gaze possibly reinforces the possibility of masking the truth in the name of a personal status and power in the group in which it is inserted ${ }^{(19)}$. The perfect body cult has become a way of life, the fascinating promise of an additional gain in health, youth and beauty has conquered an unprecedented space in scientific and artistic circles, in the media, in all spheres of our daily life. It is noted the current appreciation of the human body everywhere and the multiplication of techniques and therapies widely disseminated and progressively accessible so that each one perfects and intensifies good form, beauty, physical and mental vigor ${ }^{(7)}$.

The results demonstrate that the practice of bodybuilding is a motivating factor for the use of AS for the purpose of body alteration that has partial confirmation only with the finding of this mismatch between health objective and strategies of aesthetic construction and reconstruction in the search for rapid change of appearance. Considering only this result, it can be suggested that there is a tendency to seek bodily alteration, and it would find in bodybuilding its main motivation for $A S^{(1)}$. The research data are indicators that in the search for the perfect body the evaluated adolescents tend to put to test the practice of bodybuilding as a component of health promotion. There is evidence of predisposition to the indiscriminate consumption of AS to resolve an immediacy of dominant social patterns by establishing power relations in the male figure of physical force, reducing the space between "health and disease." From the practice of bodybuilding in the gym without professional guidance there is the contact and the possible consumption of AS, which may become a growing public health problem due to lack of knowledge about the real effects of the use of these substances, since adolescents seem to believe that the "healed" body can take them to other previously unattainable dimensions ${ }^{(20)}$.

\section{CONCLUSION}

Although it is possible to consider a high level of satisfaction for the variables associated with body image, adolescents consider the use of AS to achieve changes in their bodies by faster means, even knowing about health risks even without knowledge of the effects related to the use of AS for aesthetic purposes.

\section{AUTHORS' CONTRIBUTION}

$\mathrm{UO}$ and JMF collaborated with the practical part, collecting the data and assisting in the writing of the methods, discussion and final revision of the article. DSB performed the analyzed the data and edited the article.

\section{CONFLICTS OF INTEREST}

The authors declare no conflict of interest.

\section{AUTHORS DETAILS}

${ }^{2}$ Departamento de Ciências Medicas. Universidade de Campinas (UNICAMP), Campinas, SP, Brasil

\section{REFERENCE}

1. Blashill AJ, Wilhelm S. Body image distortions, weight, and depression in adolescent boys: longitudinal trajectories into adulthood. Psychol Men Masc. 2014; 15(4): 445-51.

2. Uchôa FNM, Lustosa RP, Rocha MTL, Daniele TMC, Aranha ACM. Causas e implicações da imagem corporal em adolescentes: um estudo de revisão. Cinergis. 2015; 16(4): 292-98.

3. Slater A, Tiggemannb M. Media matters for boys too! The role of specific magazine types and television programs in the drive for thinness and muscularity in adolescent boys. Eating Behaviors. 2014; 15(4): 679-82.

4. Barboza JS, Tavares, RE, Loyola YCS, Garcia JAD. Uso de anabolizantes na adolescência: questões biopsicossociais. Rev Ciênc Saúde. 2013; 3(4): 71-9.

5. Rosenberg M. Society and the adolescent self-image. Science. 1965; 148 (3671).

6. Elkins RL, King K, Nabors L, Vidourek R. School and parent factors associated with steroid use among adolescents. Journal of School Health. 2017; 87(3): 159-166.

7. Mineiro L, Silva JC, Junior OMS, Rocha RE. Uso de esteroides por frequentadores de academias de musculação cidade de Caçador-SC. Rev Bras Presc Fisiol Exe. 2016; 9(53): 321-27.

8. Abrahin OSC, Souza NSF, Sousa, EC, Moreira JKR, Nascimento VC. Prevalência do uso e conhecimento de esteroides anabolizantes androgênicos por estudantes e professores de educação física que atuam em academias de ginástica. Rev Bras Med Esporte. 2013; 19(1): 27-30.

9. Frizon F, Macedo SMD, Yonamine M. Uso de esteróides andrógenos anabólicos por praticantes de atividade física das principais academias de Erechim e Passo Fundo/RS. Rev Ciênc Farm Básica Apl. 2005; 26(3): 227-232. 
10. Santos AF, Mendonça PMH, Santos LDA, Silva NF, Tavares JKL. Anabolizantes: Conceitos segundo praticantes de musculação em Aracajú. Psicol Estudo. 2006; 11(2): 371-80.

11. Silva LSMF, Moreau RLM. Uso de esteroides anabólicos androgênicos por praticantes de musculação de grandes academias da cidade de São Paulo. Revista Brasileira de Ciências Farmacêuticas. 2003; 39(3): 327-33.

12. Brown JD. Statistics Corner. Questions and answers about language testing statistics: Confidence intervals, limits and levels? Shiken: JALT. Testing \& Evaluation SIG Newsletter. 2011; 15(1) 10-14.

13. Siegel S, Castellan JR, NJ. Estatística não-paramétrica para ciências do comportamento. Métodos de Pesquisa. 2 ed. Porto Alegre: Bookman, 2008.

14. Wickman ME, Anderson NLR, Greenberg CS. The adolescent perception of invincibility and its influence on teen acceptance of health promotion strategies. J Pediatr Nurs. 2008; 23(6): 460-68.

15. Dakanalis A, Carrà G, Calogero R, Fida R, Clerici M, Zanetti MA, et al. The developmental effects of media-ideal internalization and self-objectification processes on adolescents' negative body-feelings, dietary restraint, and binge eating. Eur Child Adolesc Psychiatry. 2015; 24(8): 997-1010.
16. Braga PD, Molina NCB, Figueiredo TAM. Representações do corpo: com a palavra um grupo de adolescentes de classes populares. Ciência Saúd Coletiv. 2010; 15(1): 87-95.

17. Couto ES, Gollner SV. Corpos mutantes: ensaios sobre novas (D) eficiências corporais. Porto Alegre: URFGS, 2007.

18. Elkins RL, King K, Nabors L, Vidourek R. School and parent factors associated with steroid use among adolescents. J Scholl Health. 2017; 87(3): 159-166.

19. Domingues SF, Marins JCB. Utilização de recursos ergogênicos e suplementos alimentares por praticantes de musculação em Belo Horizonte. Fit Perf J. 2007; 6 (4): 218-26.

20. Steiger AE, Allemand M, Robins RW, Fend HA. Low and decreasing selfesteem during adolescence predict adult depression two decades later. J Personal Soc Psychol. 2014; 106(2): 325-338. 